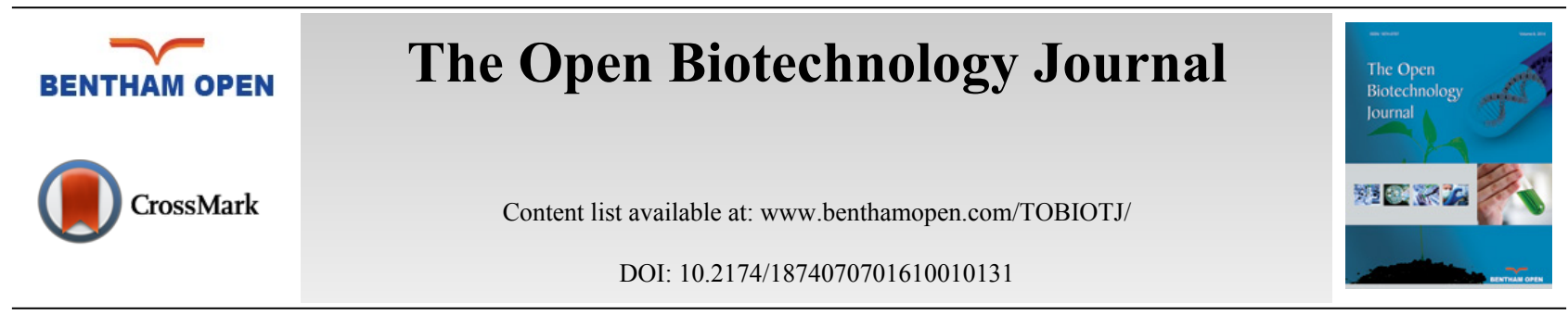

\title{
Endocrine Disruptors as Pollutants in Marine Ecosystem: A Case Study in Egypt
}

\author{
Maha Ahmed Mohamed Abdallah \\ National Institute of Oceanography and Fisheries, Marine Pollution Laboratory, Qait Bey, Alexandria, Egypt
}

\begin{abstract}
Growing populations and increasing industry and agriculture activates have increased the existence of chemicals in the aquatic environment. The variety of anthropogenic chemicals that have been identified as potential endocrine disruptors (EDCs) in the environment and the problems arising from their use as human and livestock pharmaceuticals are discussed. Sewage effluents have been identified as a source of a diverse mixture of EDCs to the aquatic environment. These waters from homes and industries include natural and synthetic hormones (estrogens, androgens), active ingredients in pharmaceuticals, metals, pesticides, personal care product additives, and industrial chemicals. Once effluents are discharged to aquatic environments, EDCs will be diluted in stream or river waters so that organisms living very close to the discharge will have the highest exposure. Aquatic organisms also readily take up and store EDCs and its metabolites. Exposure to endocrine active compounds remains poorly characterized in developing countries despite the fact that behavioral practices related to westernization have the potential to influence exposure. Thus, in Egypt for example, it is likely that women in urban areas have a higher exposure to environmental hormonal risk factors, possibly xenoestrogens (EDCs) with regards to known risk factors of uterine and breast cancer.
\end{abstract}

Keywords: Aquatic environment, endocrine disruptors, Egypt, marine organism.

\section{INTRODUCTION}

The ocean margin is a critical land-ocean interface as at its boundaries the ocean receives most of the land-based contaminant inputs. Accordingly, the existence of chemicals in the marine environment, due to industrial activities from smelters, tanneries, the textile industry, the chemical industry and urban sewage, is of serious concern owing to the toxicity of these chemicals to human and other forms of life. In recent years there has been growing concern about the release of certain chemicals (Endocrine-disrupting compounds (EDCs) into the environment which may be altering the reproductive health of humans and their endocrine systems [1].

EDCs are exogenous substances (xenoestrogens) that have been shown to act like natural hormones within the body, and have been implicated in numerous in vitro, animal, and human studies to increase the risk of breast cancer [2].

They are natural and man-made chemicals, which seem to be able to mimic or interfere with the binding and action of natural hormones, thus disrupting physiological processes. They found in the aquatic environment, and they have received attention in recent years due to the interactions in the hormonal system of organisms or humans.

These xenobiotics are discharged into rivers, lakes, groundwater, and even drinking water and oceans, where they accumulate in aquatic species [3,4].

Human exposure to these chemicals in the environment is a critical concern with unknown long-term impacts. Natural and synthetic EDCs are released into the environment by humans, animals and industry; mainly through sewage treatment systems before reaching the receiving bodies (soil, surface water, sediment and ground water). Wastewater treatment plants have been studied as a major source for EDCs. Being EDCs exist in extremely low concentration

\footnotetext{
* Address correspondence to this author at the National Institute of Oceanography and Fisheries, Marine Pollution Laboratory, Qait Bey, Alexandria, Egypt; Tel: +201007205032; Email: mahaahmed7@ymail.com
} 
( $\mu \mathrm{g} / \mathrm{L}$ or $\mathrm{ng} / \mathrm{L})$ [5].The EDCs' main distribution in the environment is illustrated in Fig. (1) [6, 7]. EDCs are a latent crisis to humans and the environment. Key to the solution for this problem is the identification of EDCs, the accurate measurement of their presence in aquatic systems, and development of methods for their elimination from the environment. Theoretically this crisis could be easily controlled, if EDCs can be completely removed from sewage at sewage treatment plants before final release into the environment.

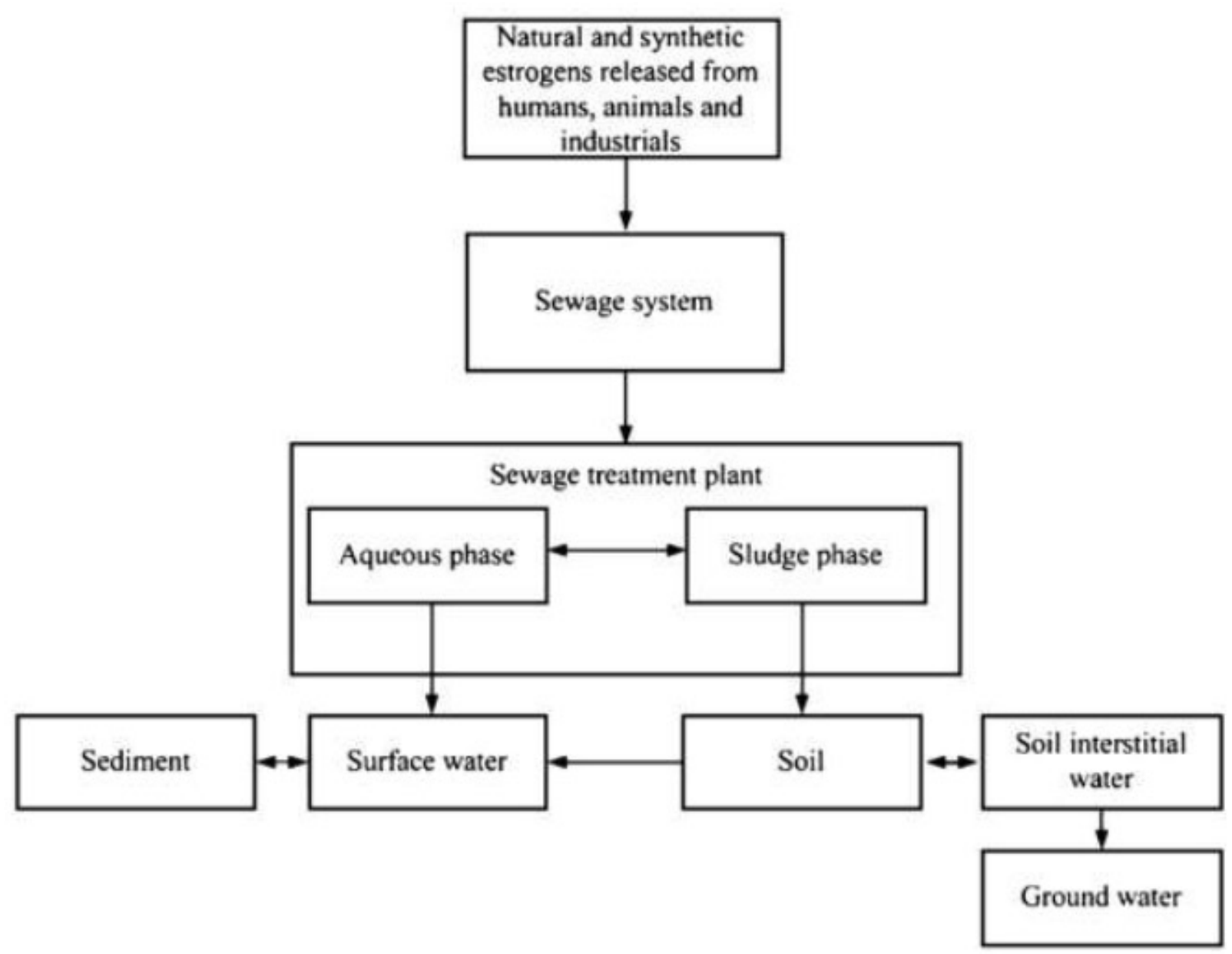

Fig. (1). EDCs distribution in the environment $[6,7]$.

EDCs removal methods fall into three categories; physical removal, biodegradation and chemical advanced oxidation (CAO).

This article provides an overview of EDCs (including their adverse effects on health and techniques for monitoring them) that brings together the issues faced by the marine environment in trying to reveal the concentration levels of these compounds in the marine organisms. Endocrine disruption needs to be assessed as part of the consideration of all potentially toxic effects of a range of emerging and as yet poorly understood contaminants in surface water and wastewater. The aim of this review is to alert those concerned with marine food to the issues and problems surrounding EDCs, especially in the context of contaminated water sources

\section{TYPES AND SOURCES OF EDCS}

Hundreds of individual anthropogenic and natural chemicals are known or suspected to interact with endocrine systems in humans and wildlife, and their sources of exposure, chemical properties, and environmental fate vary widely. Numerous EDCs are released into the environment through many routes as the result of industrial activities around the world [8]. The list of known EDCs is extensive and includes natural and synthetic hormones, anthropogenic chemicals possessing estrogenic activity. These estrogenic pollutants range from the organochlorine pesticides, which include 
DDT 1,1,1-Trichloro-2,2'bis( $p$-chlorophenyl) ethane, aldrin, and dieldrin, fungicides, detergents to polychlorinated biphenyls, dioxins and furans as Polybrominated Diphenyl Ethers (PBDEs), alkyl phenol polyethoxylates, Bisphenol A, Nonylphenol, Bisphenol A diglycidyl ether (BADGE), UV filters, Siloxane, pharmaceuticals Phytoestrogens (natural compounds present in plants and ingested daily by both animals and humans), phthalates, pharmaceuticals such as the synthetic estrogen $17 \alpha$-ethynylestradiol and heavy metals used in the manufacture of paints and plastics [9]. Bisphenol A (BPA) is a chemical produced in large quantities for use primarily in the production of polycarbonate plastics and epoxy resins.

The chemicals are grouped into classes based on their physical-chemical characteristics or origin/application areas (Table 1). The classes include chemicals that are currently produced for commercial purposes, and those that are no longer manufactured or are being phased out of production [10].

Table 1. Gropes of known or potential Endocrine disrupting chemicals with examples of individual EDCs [10].

\begin{tabular}{|c|c|}
\hline Classification & Specific Examples of EDCs \\
\hline Persistent Organic Pollutants (POPs) & $\begin{array}{l}\text { PCDDs/PCDFs, PCBs, HCB, Chlordan, Toxaphene, Lindan, Endosulphan, } \\
\text { Octachlorostyrene, methyl sulphones }\end{array}$ \\
\hline Plasticizers and other additives in materials and goods & $\begin{array}{l}\text { Phthalate esters, Triphenyl phosphate, n-Butylbenzene, Triclocarban, Butylated } \\
\text { hydroxyanisole }\end{array}$ \\
\hline $\begin{array}{l}\text { Polycyclic Aromatic Chemicals (PACs) including } \\
\text { PAHs }\end{array}$ & Benzo(a)pyrene, Benzo(a)anthracene, Pyrene, Anthracene \\
\hline Halogenated Phenolic Chemicals (HPCs) & 2,4-Dichlorophenol, Pentachlorophenol, Hydroxy-PCBs, Hydroxy-PBDEs \\
\hline Non-halogenated Phenolic Chemicals (Non-HPCs) & Bisphenol A, BADGE, Bisphenol F, Bisphenol S, Nonylphenol, Octylphenol, Resorcinol \\
\hline Current-use Pesticides & Carbaryl, Malathion, Mancozeb, Vinclozolin, Procloraz, Procymidone, Chlorpyrifos \\
\hline $\begin{array}{l}\text { Pharmaceuticals, Growth Promoters and Personal Care } \\
\text { Product Ingredients }\end{array}$ & Endocrine active, Selective serotonin reuptake inhibitors, Flutamide, Parabens \\
\hline Metals and Organometallic Chemicals & Arsenic, Cadmium, Lead, Methyl mercury, tributyltin, Triphenyltin \\
\hline Phytoestrogens & Isoflavones, Coumestans, Mycotoxins, Prenylflavonoids \\
\hline
\end{tabular}

In contrast to a decade ago, there is a better appreciation that industrial and consumer products can contain known or potential EDCs. For example, cosmetics and other personal care products (shampoos and other hair products, toothpaste, soaps, lotions) contain fragrances (e.g. galaxolide), solvents (e.g. cyclic methyl siloxanes), preservatives (e.g. parabens), and plasticizers e.g. phthalate esters), antimicrobials (e.g. triclosan), chemical stabilizing agents (e.g. phthalates), and metals (e.g. lead, arsenic, mercury). Most are added intentionally to these products but some may be contaminants with no added obvious benefit.

\section{ACTION OF THE ENDOCRINE CHEMICAL DISRUPTOR}

\section{Phenols Compounds}

\subsection{Bisphenol $A$}

Bisphenol $\mathrm{A}$ is a suspected environmental endocrine disruptor that has been shown to interfere with the reproductive system. Recent finding showed that BPA represented the estrogenic activity at a low dose of $0.23 \mathrm{pg} / \mathrm{ml} \mathrm{culture}$ medium [11]. It may increase carcinogenic risk, cardiovascular diagnosis and diabetes in humans [12, 13]. BPA has been demonstrated to be both estrogenic and anti androgenic, leading to the decrease in sperm production in humans and abnormal development of puberty in experimental animals [14].

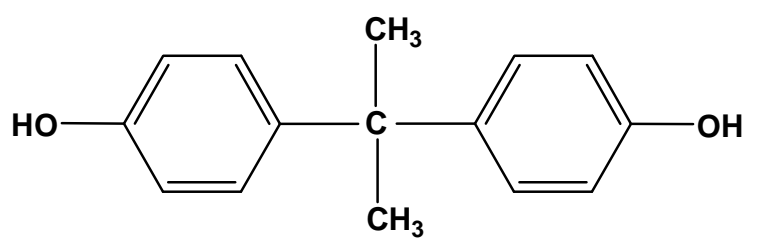

BPA, 2,2-bis-(4-hydroxyphenyl)propane 
Many in vitro and in vivo assays had confirmed that Bisphenol A increased the incidence of infertility, genital tract abnormalities and breast cancer [15]. National Institutes of Health in Norway reported that there was a concern about BPA's effects on fetal and infant brain development and behavior. A recent report by the U.S. National Toxicology Program (NTP) agreed with the panel, expressing concern for effects on the brain, behavior, and prostate gland in fetuses, infants, and children at current human exposures to Bisphenol A, and minimal concern for effects on the mammary gland and an earlier age for puberty for females in fetuses, infants, and children at current human exposures to Bisphenol A. Accordingly, there is an urgent need for developing the effective technology to remove Bisphenol A from aquatic environment [16].

Environmental estrogens include, but are not limited to, chemicals that mimic the female sex hormone 17- $\beta$ estradiol. Comparing structure-activity relationships for estrogenicity of NP and 17- $\beta$-estradiol, analysis of the data compared to $17-\beta$-estradiol structure identified three structural criteria that were related to xenoestrogen activity and potency: (a) a hydrogen bonding ability of the phenolic ring mimicking the A-ring, (b) a hydrophobic centre similar in size and shape to the B- and C-rings, and (c) a hydrogen-bond donor mimicking the 17 - $\beta$-hydroxyl moiety of the Dring, especially with an oxygen-to-oxygen distance similar to that between the 3 - and 17- $\beta$-hydroxyl groups of 17- $\beta$ estradiol [17, 18]. Moderately active compounds, such as NP, have a 4-hydroxyl substituted benzene ring with a hydrophobic moiety equivalent in size and shape to the B- and C-ring of 17- $\beta$-estradiol (Fig. 2).
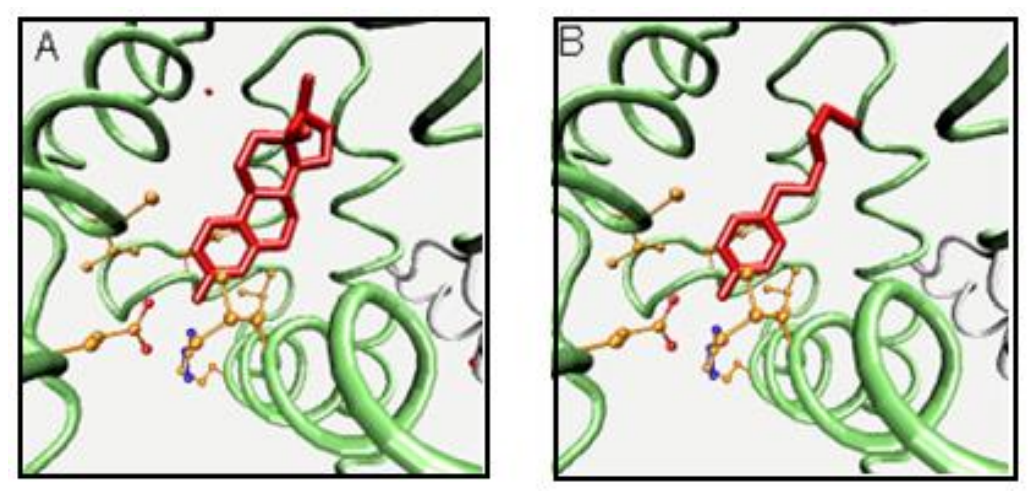

Fig. (2). 17- $\beta$-Estradiol (A) and nonylphenol (B) as ligands for the estrogen receptor.

\subsection{Bisphenol A Diglycidyl Ether (BADGE)}

Bisphenol A diglycidyl ether (BADGE) is a building block of epoxy resins that coat food and beverage cans and is used as a monomer in the production of epoxy-based polymers as well as an additive for the elimination of surplus hydrochloric acid in polyvinyl chloride (PVC) organosol production. BADGE is present in many canned foods and is absorbed through the gastrointestinal tract [19].

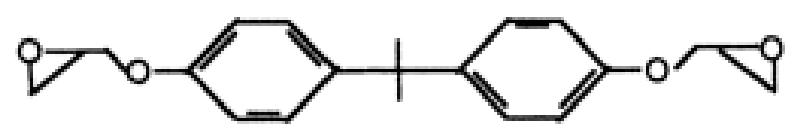

Bisphenol A Diglycidyl Ether (BADGE)

Therefore, a migration limit of $1 \mathrm{mg} / \mathrm{kg}$ for BADGE and its hydrolytic and chlorinated derivatives including bisphenol A (2,3-dihydroxypropyl) glycidyl ether (BADGE- $\mathrm{H}_{2} \mathrm{O}$ ), bisphenol A (3-chloro-2-hydroxypropyl) (2,3dihydroxypropyl) ether $(\mathrm{BADGE} \cdot \mathrm{HCl} \cdot \mathrm{H} 2 \mathrm{O})$, and bisphenol A bis (2,3-dihydroxypropyl) ether $\left(\mathrm{BADGE} \cdot 2 \mathrm{H}_{2} \mathrm{O}\right)$, has been set by the European Commission for food contact applications products have been reported $\mathrm{BADGE} \cdot 2-\mathrm{H}_{2} \mathrm{O}$, a hydrolysis product of BADGE, was shown to exhibit estrogenic activity, even greater than that of BPA [20]. BADGE has been reported to form DNA adducts, and to elicit teratogenic and mutagenic effects in vitro. In addition to genotoxic effects of BADGEs, cytotoxicity, developmental, and reproductive toxicity have been reported in laboratory animals. Male workers exposed to BADGE had lower levels of follicle stimulating hormone than the reference population. 
Following oral and/or dermal exposure, BADGE is metabolized to bis-diols by epoxide hydrolase. As a stable metabolite of BADGE, BADGE $\cdot 2 \mathrm{H}_{2} \mathrm{O}$ was also reported as an endocrine disruptor, with potentials even greater than those of bisphenol A (BPA), a known endocrine disrupting chemical. Further, antagonistic activity of the chlorohydroxy derivative of BADGE toward androgen has been reported. Studies also have shown that BADGE was not transformed into BPA by the mammalian metabolic system [21].

\subsection{Nonylphenol}

Nonylphenol is one of the most studied estrogen mimics that appear to interact with development in several organisms. Table 2 shows several effects on different organisms including mollusks, crustaceans, fishes, amphibians, and other vertebrates. Several endocrine alterations have been found after exposure to NP at concentrations ranging from 0.1 to $100 \mu \mathrm{gL}^{-1}$ (Table 2).

Table 2. Effects on different organisms after treatment with environmental concentrations of Nonylphenol.

\begin{tabular}{|c|c|c|c|}
\hline Nonylphenol Effects & Organism & $\begin{array}{c}\text { Concentration } \\
\left(\mu \mathrm{gL}^{-1}\right)\end{array}$ & Reference \\
\hline $\begin{array}{l}\text { - Developmental abnormalities. } \\
\text { - Reduction in larval survival. } \\
\text { - Delayed settlement and metamorphosis. }\end{array}$ & $\begin{array}{l}\text { Crassostrea } \\
\text { gigas }\end{array}$ & $0.1-10$ & {$[22]$} \\
\hline $\begin{array}{l}\text { - Changes in the sex ratio towards females. } \\
\text { - Increase in the incidence of hermaphrodites }\end{array}$ & $\begin{array}{l}\text { Crassostrea } \\
\text { gigas }\end{array}$ & $1-100$ & {$[23]$} \\
\hline $\begin{array}{l}\text { - Perturbations of endogenous steroid metabolism. } \\
\text { - Reduction of the testosterone elimination } \\
\text { - Increase of the testosterone conversion rate. }\end{array}$ & Daphnia magna & $10-40$ & {$[24]$} \\
\hline $\begin{array}{l}\text { - Increase of fertility. } \\
\text { - Longer second antennae. }\end{array}$ & $\begin{array}{l}\text { Corophium } \\
\text { volutator }\end{array}$ & 10 & {$[25]$} \\
\hline - DNA adduct formation, and mutations or genomic rearrangements. & $\begin{array}{l}\text { Elminius } \\
\text { modestus }\end{array}$ & $0.1-10$ & {$[26]$} \\
\hline $\begin{array}{l}\text { - Mortality increase. } \\
\text { - Morphologic deformations. } \\
\text { - Apoptosis increase } \\
\text { - Alteration of the deposition and differentiation of neural crest-derived melanocytes. }\end{array}$ & Xenopus laevis & $\begin{array}{c}0-50 \\
0.1-10\end{array}$ & {$[27]$} \\
\hline $\begin{array}{l}\text { - Increase of mortality rates. } \\
\text { - Stress behavior. } \\
\text { - Decrease of body weight. } \\
\text { - Reduction of gonadal development and reproductive function. }\end{array}$ & $\begin{array}{l}\text { Xiphophorus } \\
\text { maculates } \\
\text { Xiphophorus } \\
\text { helleri }\end{array}$ & 14 & [28] \\
\hline $\begin{array}{l}\text { - Feminization of the phenotype. } \\
\text { - Intersex "testis-ova" condition. }\end{array}$ & Salmo salar & $\begin{array}{c}10-125 \\
(\mathrm{mg} / \mathrm{kg} \mathrm{BW})\end{array}$ & [29] \\
\hline $\begin{array}{l}\text { - Reduction in microsomal integrity. } \\
\text { - Negative effect on spermatogenesis and sperm quality. }\end{array}$ & mice & $\begin{array}{c}50-500 \\
\text { (drinking water) }\end{array}$ & {$[30]$} \\
\hline
\end{tabular}

Nonylphenol has been proposed to act via the androgenic gland in Malacostracan crustacean. This gland is present only in males and regulates sexual differentiation and development of secondary sexual characteristics through a protein known as androgenic hormone [31]. An increase of fertility in C. volutator females was observed in NP exposed populations while the sex ratio was not affected. Additionally, the second antennae of exposed male animals were observed to be significantly longer that those of control animals [25].

Nonylphenol has also been suggested to induce DNA adduct formation, and/or mutations or genomic rearrangements. This DNA damage could help explain how xenoestrogens mimic the effects produced by natural estrogens [26]. Other studies have shown that exposure to 100 and $200 \mu \mathrm{gL}-1$ of NP are not directly embryogenic but rather that toxicity is mediated by maternal influences during gestation. Nonylphenol affects the weight of reproductive organs and kidneys in parental and males of CD-I mice. In females these effects were only seen in the parental organisms. A significant reduction in microsomal integrity has been reported in both generations of NP-treated mice as well as a negative effect on spermatogenesis and sperm quality [31].

\section{UV Filters}

UV filters are lipophilic high production volume substances with an increasing diverse spectrum of use, as sunscreens or product protection in cosmetics, as additives in plastics, folia, carpets, furnish clothing and washing powder. UV Filters have to be declared in cosmetics but remain essentially unidentified in technical products. Possible 
exposure scenarios are many folds as humans and animals can be exposed through the food chain and humans through skin [32]. UV filters represent a new class of endocrine active chemicals. In vitro, 8/9 chemicals showed estrogenic (MCF-7 cells), and 2/9 antiandrogenic activity (MDA-kb2 cells). Six/nine filters (benzophenone (Bp)-1, Bp-2, Bp-3, 3benzylidene camphor (3-BC), 4-methylbenzylidene camphor (4-MBC), octyl-methoxycinnamate (OMC)) increased uterine weight in immature rats.

3-Benzylidene camphor and 4-MBC displaced $16 \alpha^{125}$ I-estradiol from human estrogen receptor (ER) $\beta$, not ER $\alpha$. Developmental toxicity of 4-MBC (0.7-47 mg/kg body weight/day) and 3-BC (0.24-7 mg/kg), administered in chow was investigated in Long

Evans (LE) rats. Weight gain of pregnant rats was reduced only by 3-BC, early postnatal survival rate and thymus weight by both compounds at higher doses. 4-Methylbenzylidene camphor and 3-BC delayed male puberty, and dosedependently affected reproductive organ weights of adult male and female F1 offspring, with partly different effect patterns. Thyroid weight was increased by higher 4-MBC doses. Tissue-specific changes in mRNA levels of estrogenregulated genes in prostate, uterus and brain regions, determined by real-time PCR, and in their response to acute estradiol challenge in adult gonadectomized offspring were observed [32, 33].

\section{Siloxane}

The cyclic siloxane octamethylcyclotetrasiloxane (D4) and the linear siloxane hexamethyldisiloxane (HMDS) have numerous industrial and consumer applications and thus have the potential for human exposure. In an uterotrophic assay in immature rats receiving oral doses of D4 and HMDS for 4 days, D4 exhibited weakly estrogenic effects (dose-related increase in uterine weight and epithelial cell height) in both SP and F-344 rats. The substance also showed weak antiestrogenic properties by partially blocking EE (ethinylestradiol) induced uterine weight increases (competitive inhibition of estrogen receptor binding or D4 acting as a partial estrogen agonist). Estrogenic and antiestrogenic effects of D4 were several orders of magnitude 50 less potent than EE, and many times less potent than the weak phytoestrogen CE [34].

In the same assay HMDS showed no measurable effect on uterine weight when tested as an agonist. When coadministered together with EE, HMDS produced a slight, but statistically significant reduction in absolute uterine weight. The biological relevance of this could not be assessed in the present study [35].

\section{Polybrominated Diphenyl Ethers (PBDEs)}

\subsection{Thyrotoxicity}

Hydroxy-PBDE have structural similarities with the thyroid hormones 3,5-diiodothyronine (T2), 3,3,5triiodothyronine (T3) and 3,3,5,5-tetraiodothyronine (thyroxine, T4). They have been reported to bind human alpha- and beta-thyroid hormone receptors. PCBs and PBDEs both alter thyroid hormone balance by disrupting brain development. PBDEs also bind to cytosolic aryl hydrocarbon receptors, thyroid hormone receptors, and serum thyroid hormone binding proteins (i.e., transthyretin). Specific congeners may decrease, increase, or mimic the biological action of thyroid hormones owing to structural similarities to these compounds [36].

Short-term exposure to less-brominated PBDE congeners interferes with thyroid function and disrupts hormonal balance. In metabolic studies of tetra-BDE, hydroxy-tetra-BDE metabolites were found. These hydroxy-PBDEs may reduce $\mathrm{T} 4$ levels by binding to thyroid hormone transport protein (transthyretin), interfering with normal thyroid hormone transport, resulting in decreased total thyroxine levels.

\subsection{Estrogenicity}

PBDEs are also estrogen disruptors, some hydroxy-PBDEs were more potent inducers than estradiol at higher concentrations. The concentrations of PBDEs leading to 50\% induction varied from 2.5 to $7.3 \mu \mathrm{M}$. Several pure PBDE congeners as well as OH-PBDE are agonistic of both alpha and beta-receptors and stimulate ER-mediated luciferase induction in vitro. This suggests that PBDEs may produce more potent pseudoestrogens upon in vivo metabolism that can compete with $\mathrm{T} 4$ for binding totransthyretin. Other estrogen receptor-mediated pathways affecting testis development, hepatic enzymes activity, and behavior may be affected as well [37]. 


\section{Benzothiazole (BTHs)}

Benzothiazole and its derivatives (BTHs) are used in rubber products to accelerate the vulcanization of rubbers and to enhance mechanical strength and abrasion resistance. Some benzophenone derivatives (BPs), as well as some phenolic BTRs, are efficient UV light filters and are widely used in plastics and other polymeric materials. The acute toxicities of BTRs, BTHs, and BPs were reported to be low. Human intake of benzophenones occurs from food and medicine, and these chemicals may accumulate in the body to some extent. However, various adverse effects from chronic exposure to these compounds have been reported. Mutagenicity and estrogenic potential of 1-H-BTR have been reported in bacteria and aquatic organisms. 1-H-BTR and tolyltriazole (TTR, a mixture of isomers of 4-methyl-1-HBTR and 5-methyl-1-H-BTR) were phytotoxic.

Some hydroxylated benzophenones also show estrogenic activity in the yeast two hybrid system with estrogen receptor and coactivators [38]. It was reported that 2-hydroxy-4-methoxybenzophenone (2-OH-4-MeO-BP) and 4hydroxybenzophenone (4-OH-BP) are weakly positive in the uterotrophic assay using immature rats [39]. Androgenic and anti-androgenic properties of hydroxylated benzophenones are also an important problem. Yamasaki et al. [40] reported that some hydroxybenzophenones do not act as antiandrogen in the Hershberger assay and Satoh et al. [41] showed that benzophenone has no affinity for androgen receptor. While Ma et al. [42] reported that 2-OH-4-MeO-BP is a weak antagonist for androgen receptor. However, the activities in reporter assays have not been fully examined, and the relationship between the structure and activity of benzophenone derivatives is not yet understood.

The in vivo activity results obtained by Suzuki et al. [43] suggest that benzophenones pose a relatively low risk to humans in terms of endocrine disrupting, in spite of the in vitro activity. In contrast, some hydroxylated benzophenones, such as those hydroxylated at the 2 and 4-positions, showed both estrogenic and antiandrogenic activities, and the presence of other hydroxyl groups markedly alters these activities. Thus, these compounds might exhibit endocrine disrupting action via both mechanisms in animals.

\section{DDT}

\subsection{Sex Steroid Axis}

The effect of DDT and its metabolites on the reproductive system has been a primary focus of many researches. Kelce et al. [44] reported that $p, p^{\prime}$-DDE, the major and persistent DDT metabolite, has little ability to bind with the oestrogen receptor, it does bind strongly with the androgen receptor and inhibits androgen receptor action via the inhibition of androgen-induced transcription. DDT or DDE may alter sex hormone metabolism, reducing available testosterone to tissues [45].The authors suggested that $p, p^{\prime}$-DDE can cross the placenta to the developing human fetus and reach levels shown, in rats, to induce anti-androgenic effects in vivo. Because of concerns about DDT storage in fat, several attempts have been made to estimate the relation between DDT levels in breast fat and breast cancer incidence. Falck et al. [46] showed that women with malignant breast cancer had significantly higher mammary adipose tissue levels of $p, p^{\prime}$-DDT and the metabolite $p, p^{\prime}$-DDE than women with benign changes.

\subsection{Thyroid Axis}

Given their wide spectrum of steroid action, it is not surprising that DDT and its metabolites could affect axis in the endocrine system. For example, DDT causes hyperthyroidism and enlargement of the thyroid. Xenobiotic compounds like DDT and its metabolites exert an effect on the thyroid by disrupting one of the several possible steps in the biosynthesis and/or secretion of thyroid hormones. These steps include (1) inhibition of the iodine-trapping mechanism (thiocyanate or perchlorate), (2) blockage of organic binding of iodine and coupling of iodothyronine to form thyroxin (T4) and triiodothyronine (T3) or (3) inhibition of T3/T4 secretion by an effect on proteolysis of active hormone from the colloid [47]. DDT has been shown to disrupt thyroid hormone economy by increasing the peripheral metabolism of thyroid hormones through an induction of hepatic microsomal enzymes. The effect of DDT and its metabolites have been reported in several species. Male juvenile alligator from Lake Apopka, Florida (dicofol and DDT spill in 1980,s), have elevated plasma T4 levels compared to male juvenile alligators in lake Woodruff, Florida [48].

\subsection{Adrenal Axis}

Guillette et al. [49] suggested that DDT could have corticosterone like action in anurans. They described facial abnormalities in metamorphic froglets after exposure of Kassina senegalensis tadpoles to corticosterone. These effects are identical to those reported in other anurans larvae after DDT exposure. Guillette et al. [49] has hypothesized that the 
effect of corticosteroneis due to its stimulation of DDT release from fat stores. Antiadrenal action of $o, p^{\prime}-$ DDD and $o, p^{\prime}$-DDE are well documented [50]. As $o, p^{\prime}$-DDD inhibits adrenal steroidgenisis in variety of species. Including human, dogs, various fish species, and birds, but does not affect adrenal steroidgenisis in sheep, tiger salamanders or tree lizards.

\section{Polychlorinated Biphenols (PCBs)}

During the last decade there has been increasing concern about the endocrine disruptive effects of many OCs (Organic Chemicals) in humans as well as in wildlife species [51]. Many environmental compounds, including the pesticides 2,4-D and DDD and the industrial chemicals PCBs and dioxins, interfere with thyroid hormone processes [52]. The thyroid system is one of the endocrine systems affected by PCBs [53]. The substances can affect hormone production by altering iodide use and delivery. They can affect thyroid enzymes that put together or take apart the hormones. They can alter thyroid hormone delivery to body tissues by changing blood transfer protein concentrations. Thyroids (THs) also stimulate the uptake of oxygen in most metabolically active tissues, and TH regulation is essential for maintaining normal body temperature [54]. Zoeller have suggested that effects of PCBs on brain development may be caused by their ability to affect the thyroid system [55]. There are two main types of THs: thyroxin (T4) and triiodothyronine (T3), which contain four and three iodine atoms, respectively. Substances can disrupt nearly every part of thyroid hormone production, delivery, and breakdown. But, unlike estrogens, androgens, and other steroid hormones, they do not strongly interfere with thyroid receptors.

Additionally, some PCBs and their breakdown products double up on thyroid hormones. First, they can tie up thyroid transport proteins in the blood leaving natural thyroid hormones without an escort. Secondly, the compounds boost certain hormone destroying liver enzymes. In essence, the free-floating thyroid hormone is filtered from the blood into the liver, quickly coated with sugar, and excreted out of the body. Thyroid hormone levels fall, and the thyroid gland balloons into a goiter. Enlarged thyroid glands have been observed in wildlife, such as herring gulls and rainbow trout, living in the Great Lakes region [56].

PCBs/dioxins disrupt the TH system by decreasing blood TH levels, which in turn induces hypothyroidism in various organs. Prenatal exposure to PCBs/dioxins in laboratory animals induces a decrease in plasma T4 levels without significantly altering the growth [57], and T3 levels remain within the normal range [58], indicating that the toxicity of these chemicals does not manifest by altering blood TH levels. On the other hand, because the molecular structures of PCBs/dioxins are similar to those of $\mathrm{TH}$, these chemicals are considered to act via TH receptors (TRs) [59]. Furthermore, these compounds can be transferred across the blood-brain barrier and accumulate in the brain [60]. These findings suggest that PCBs/dioxins induce abnormal brain development by directly acting on TR.

\section{Cadmium}

The prominence of estrogens in the etiology of breast cancer suggests that environmental exposures to chemicals that mimic effects of estrogens may be potential risk factors for the disease [61]. A new class of environmental estrogens referred to as metalloestrogens has been identified. Metalloestrogens include the heavy metals and metalloids cadmium, aluminum, antimony, arsenate, barium, cobalt, copper, chromium, lead, mercury, nickel, nitrite, selenite, tin, uranium and vanadate $[62,63]$.

Cadmium has the potential to disrupt endocrine function by behaving like sex hormones [64]. At low concentrations the metal mimics the effects of estradiol and binds with high affinity to the hormone-binding domain of ER-alpha (Estrogen Receptor- $\alpha$ ). This binding involves several amino acids, suggesting that cadmium activates the receptor through the formation of a complex with specific residues in the hormone-binding domain [64, 65]

\subsection{Estrogenic Effects of Cadmium}

A study by Johnson et al. [65] shows that, cadmium might also cause early puberty and possibly breast cancer. Roy et al. [66] has also shown that even low doses and short term exposure to cadmium can cause specific DNA damage in breast tissue and may be a possible mechanism of action of cadmium on the cell cycle of human mammary cell lines. The MCF-7 cells are a hormone dependent human breast cancer cells that require estrogens for growth [67]. Cadmium significantly stimulated the growth of MCF-7 cells when compared with cells grown in estrogen-depleted medium, comparable with the degree of growth stimulated by estradiol $[68,69]$. This study demonstrates that cadmium induces cell growth, and may have a possible role in the etiology or progression of breast cancer. 


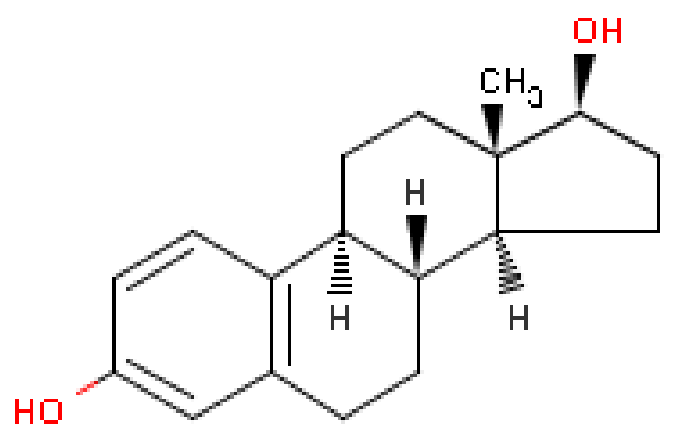

Estrogens Hormone structure

Additional evidence shows that cadmium also activates the non-genomic ER $\alpha$ pathways [68, 70]. More importantly, at a dose similar to the World Health Organization Provisional Tolerable Weekly Intake (PTWI $0.007 \mathrm{mg} / \mathrm{kg}$ body weight), cadmium mimics the in vivo effects of estrogen in target organs in animal studies [65]. Similar to estrogens, exposure of ovaryectomized animals to a low dose of cadmium $(5 \mu \mathrm{g} / \mathrm{kg}$ body weight) results in the induction of estrogen target genes and an increase in uterine wet weight that are blocked by an anti estrogen.

\subsection{Androgenic Effects of Cadmium}

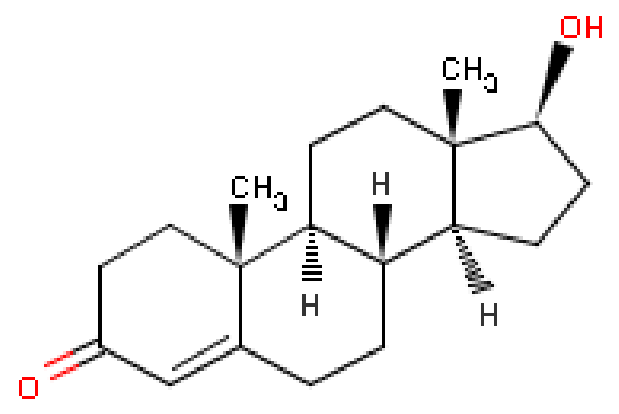

\section{Androgens Hormone Structure}

Several studies suggest that exposure to cadmium is a risk factor for prostate cancer; however, not all epidemiological studies support a role for the metal in the etiology the disease. The first studies to suggest a link between cadmium and prostate cancer showed an increased risk of the disease in occupationally exposed workers in a nickel cadmium battery factory. Several additional occupational studies demonstrated an association between cadmium exposure and an increase in prostate cancer risk and mortality [71]. The latter studies found that prostate cancer was associated with dietary exposure to cadmium through drinking water and food [72]. More importantly, environmentally relevant doses of cadmium mimic the effects of androgens in castrated rats and mice.

A recent study by Nagata et al.. investigated the association between urinary cadmium levels and estrogens and androgens in 164 postmenopausal Japanese women [73]. Their results revealed a significant positive association for cadmium exposure and testosterone levels. The cross-sectional nature of this study limits assessing the relationship between timing of cadmium exposure and hormonal changes. Cross-sectional studies may also involve length biased sampling, over-representing cases with a long duration and under representing those with a short duration of breast cancer. Also, the small sample size and possible confounding with other unmeasured factors makes the results of this study preliminary. Taken together, these data suggest that cadmium is also a metalloandrogen and may explain, in part, the risk of prostate cancer associated with exposure to the metal. 


\section{Phytoestrogens}

Phytoestrogens are plant compounds that have effects similar to those of estrogen, the major female sex hormone, in the body. They can be divided into two main groups: isoflavones, which are found in soybeans, red clover, kudzu root, among others; and lignans (Fig. 3), substances that are found in flax seed, whole grains, and some fruits and vegetables. Soy is a unique dietary source of the much studied isoflavones called genistein and daidzein.<smiles>[R3]c1cc2occ(-c3ccc(O)cc3)c(=O)c2c([R])c1[R]</smiles>

(a)<smiles>C/C=C/c1cc(OC)c2c(c1)O[C@H](c1cc(OC)c(OC)c(OC)c1)[C@H](C)O2</smiles>

(b)

Fig. (3). Isoflavones (a) and Lignans (b).

Phytoestrogens are thought to compete with natural estrogens for estrogen receptors on cells. By binding to the receptors, phytoestrogens prevent estrogen from stimulating certain tissues and theoretically lower the risk of developing cancers that are spurred by estrogen. Isoflavones are much more potent than lignans when it comes to interacting with estrogen receptors in the body. Although they compete for the same binding sites on cells, phytoestrogens do not act exactly the same way natural estrogens do. Chemically, for example, isoflavones are only about one-thousandth as potent as natural estrogens. But in some of the body's tissues, phytoestrogens mimic the action of estrogen and may alleviate the symptoms of menopause in older women; in other tissues, they block the action of estrogen and thereby lower the risk of developing some kinds of cancer, especially of the breast cancer [74].

\subsection{Phytoestrogens in Males}

The use of phytoestrogens (as soy protein) in fast food meals and other processed foods as a low cost substitute for meat products may lead to consumption of isoflavonoids by fast food eaters. A research team speculates that, such intake may lead to a slight decrease in male fertility, including a decrease in reproductive capability if isoflavones are taken in excess during childhood [75]. In theory, exposure to high levels of phytoestrogens in males could alter their hypothalamic-pituitary-gonadal axis. However, studies have shown that such a hormonal effect is minor. It may have health benefits for males [76]. Isoflavones supplementation has no effect in sperm concentration count or motility and shows no changes in testicular or ejaculate volume. Researchers are studying if phytoestrogens can prevent prostate cancer [77].

\subsection{Phytoestrogens in Females}

There are conflicting studies, and it is unclear if phytoestrogens have any effect on the cause or prevention of cancer in females. Epidemiological studies showed a protective effect against breast cancer, in vitro studies concluded that females with current or past breast cancer should be aware of the risks of potential tumor growth when taking soy products, as they can stimulate the growth of estrogen receptor-positive cells in vitro. The potential for tumor growth was found related only with small concentration of genistein (kind of isoflavones found only in soy) and protective effects were found with larger concentrations of the same phytoestrogen. Messina et al. [78] stated the opinion that not enough information is available, and that even if isoflavones have mechanisms to inhibit tumor growth, in vitro results justify the need to evaluate, at cellular level, the impact of isoflavones on breast tissue in females at high risk for breast cancer. The generally accepted position on this topic is that phytoestrogens may be beneficial for healthy females and that females with known breast cancer should be aware of potential risks and consider avoiding consumption until more information is available [79]. 


\section{OCCURANCE OF EDCS IN AQUATIC ENVIRONMENT}

Sewage effluents have been identified as a source of a diverse mixture of EDCs to the aquatic environment. These waters from homes and industries include natural and synthetic hormones (estrogens, androgens), active ingredients in pharmaceuticals, metals, pesticides, personal care product additives, and industrial chemicals [80]. In areas of food production, storm runoff from agricultural fields is an important non point source of EDCs (pesticides, hormones, pharmaceuticals) to aquatic systems.

Animal wastes are also washed into surface waters by rainfall and contain endogenous hormones, growth promoters and pharmaceuticals. Other EDCs are found in the sludge (biosolids) that remains after sewage is treated [81]. If these solids are applied to fields, EDCs like triclosan are found in nearby surface waters [82].

Bisphenol A had been detected in all kinds of environmental water, the primary sources of Bisphenol A released to environmental water are expected to be the discharge of municipal effluent and industrial wastewater, also can be encountered in raw water $[83,84]$. The maximum concentrations reached up to $17.2 \mathrm{mg} / \mathrm{L}$ in hazardous waste landfill leachates [85], $12 \mu \mathrm{g} / \mathrm{L}$ in stream water [86] and $0.1 \mu \mathrm{g} / \mathrm{L}$ in drinking water. BPA was shown to be present in Dutch, Netherlands, surface water at levels up to $330 \mathrm{ng} / \mathrm{l}$, and one occasional level of $21 \mu \mathrm{g} / \mathrm{l}$. Also in other studies, In 1997 BPA was found in Dutch surface water at levels varying from 4 to $160 \mathrm{ng} / \mathrm{l}$ [87]. Similarly, in a German study, BPA levels in surface water ranged from $0.5-229 \mathrm{ng} / 1$ with a median of $23 \mathrm{ng} / 1$ [88]. Crain et al. [89] note that although BPA dissolved in surface water has a short half-life because of photo- and microbial degradation, metabolites may persist. Additionally, while most values reported for BPA in surface water are below $1 \mu \mathrm{g} / \mathrm{L}[90]$, BPA concentrations can vary with depth [90] so sampling throughout the water column may be necessary to accurately characterize BPA. Observed BPA concentrations in oceans and estuaries are relatively low compared to some fresh water systems. However, BPA leaching could be a concern at marine sites where plastic waste has accumulated, as BPA leaches more rapidly in marine than in freshwater systems [89, 91] and microbial degradation may occur more slowly [92].

Nonylphenol (NP) which are non-ionic Surfactants and widely used in many industries can cause several hazards to aquatic ecosystem. Pesticides are thought to be a secondary source of NP contamination in natural water because Nonylphenol ethoxylates (NPEOs) are used as adjutants in pesticide formulations [93]. However, most wastes are first passed through a wastewater treatment plant. Most of the NP containing compounds, such as (NPEOs), is then aerobically degraded by bacteria into shorter Nonylphenol ethoxylates or NP. In the wastewater treatment plant, it is estimated that half of the NP absorbs on particles. These particles then stay in the wastewater treatment plant as sludge or are emitted into the aquatic phase and settle on the sediment [94]. The concentration values for NP in sediments are several orders of magnitude higher that those found in surface waters, and can reach concentrations up to $13.700 \mu \mathrm{gkg}^{-1}$ [18]. It appears that degradation of Nonylphenol in sea water and sediments may be slower than in fresh water and freshwater sediments. Bennie et al. [95] measured Nonylphenol in Great Lakes water; they found about 25 percent of sites sampled had concentrations from 0.01 to $0.92 \mu \mathrm{g} / \mathrm{L}$.

DDT may reach surface waters primarily by runoff, atmospheric transport, drift, or by direct application (e.g. to control mosquito-borne malaria). The reported half-life for DDT in the water environment is 56 days in lake water and approximately 28 days in river water. The main pathways for loss are volatilization, photodegradation, adsorption to water-borne particulates and sedimentation. Many studies indicate that bottom sediments in lakes and rivers act as reservoirs for DDT and its metabolites. Despite a twenty-year ban in the USA, It is still found concentrated in soils and freshwater sediments. Field and laboratory studies in the United Kingdom demonstrated that very little breakdown of DDT occurred in estuary sediments over the course of 46 days. DDT has been widely detected in ambient surface water sampling in the United States at a median level of $1 \mathrm{ng} / \mathrm{L}$ [96].

In aquatic environment, PCBs bind readily with sediment particles and do not easily dissolve in water. In estuaries and rivers, PCBs bind to sediment particles one million times more strongly than to water molecules. PCBs molecules attached to sediment particles eventually sink to the estuary or river bottom, where they are eaten by bottom fauna. These smallest aquatic organisms are eaten by successively larger, predator fish which are then consumed by fish-eating mammals. The PCBs in surface sediments of Egyptian Mediterranean coast are predominant over all kinds of pesticides the concentration was ranged from 0.31 to $1.95 \mathrm{ng} / \mathrm{g}$ [97].

Polybrominated Diphenyl ethers (PBDEs) have been detected in coastal and estuarine environments. They have also been found in the air, soil, sediments, humans, wildlife, fish and other marine life, and sewage treatment plant sludge [98]. 
Cadmium, Lead and Arsenic, as a metallic hormone, can enter surface waters from the natural sources and from a variety of manufacturing operations that involve either cadmium itself or zinc that contains a cadmium impurity. Cadmium and Lead can enter the water environment from the plating operations when spent plating solutions are discarded. The production of refined metals is a potential source of $\mathrm{Cd}$ and $\mathrm{Pb}$ in nearby surface waters. Lead can also enter the aquatic environment from the boats have been painted with a paint that is high in lead [99].

\section{OCCURRENCE OF EDCS IN MARINE ORGANISMS}

Both marine and freshwater fish are exposed to a variety of EDCs from a range of sources. Effluents from industrial sites containing EDCs such as alkylphenol ethoxylates or Bisphenol A, urban and agricultural runoff which contains a number of endocrine disrupting pesticides and residues, sewage effluent which has shown to exert an oestrogenic effect on male fish, and sewage sludge dumped at sea all result in the exposure of fish to EDCs (Fig. 2). Once effluents are discharged to aquatic environments, EDCs will be diluted in stream or river waters so that organisms living very close to the discharge will have the highest exposure. Although some EDCs are not persistent in waters (e.g. estrogens persist days to weeks), there is a constant discharge and fish and other organisms are continuously exposed to a mix of persistent and "pseudo persistent" chemicals. Additional exposure sources, especially in marine environments, are accidental or intentional discharges from oil tankers, ships and fuel extraction activities and oil spills [10].

Bisphenol A has an acute toxicity to aquatic organisms in the range of 1-10 $\mathrm{mg} / \mathrm{L}$ for freshwater and marine species. Examples of $\mathrm{LC}_{50}$ values are $1.1 \mathrm{mg} / 1$ for shrimp and $4.7 \mathrm{mg} / \mathrm{L}$ for minnow [100] and of $\mathrm{EC}_{50}$ values are $10 \mathrm{mg} / \mathrm{L}$ for water flea. Belfroid et al. [87] and Lindholst et al. [101] reported that, BPA is present in the liver of rainbow trout (75 ng/g d.w), while in muscle; the levels remained below the limit of detection ( $5 \mathrm{ng} / \mathrm{g} \mathrm{d.w})$. In another study of Lindholst et al. [101], rainbow trout were exposed to BPA during 12 days via the water phase it was observed mainly in the liver; they also detected BPA in the muscle, but at much lower concentrations. The risks of estrogenic effects of the present BPA levels in the environment can be based on the observed estrogenic response in rainbow trout [101, 92]. While BPA exposure has resulted in growth and developmental effects in fishes, this has only been found to occur above typical environmental levels. Alo et al. [102] found $80 \mu \mathrm{g} / \mathrm{L}$ BPA altered the activity of neural estrogen receptors that regulate growth hormone in Mediterranean rainbow wrasse (Coris julis), potentially impairing reproduction and development in this sequentially hermaphroditic species. Embryonic medaka were found to exhibit increased morphological deformities from $200 \mu \mathrm{g} / \mathrm{L}$ BPA exposure [103], whereas zebrafish embryos exposed to $228 \mu \mathrm{g} / \mathrm{L}$ concentrations of BPA showed signs of feminized brains [89]. At higher BPA exposure $(1000 \mu \mathrm{g} / \mathrm{L})$ yolk sac edema and hemorrhage were observed in salmon fry (Salmo salar m. Sebago) [104]. Elshaer et al. [105] assess the histological changes and the harmful effect caused to the gill tissues of both mosquito-fish (Gambusia affinis) and a guppy-fish (Poecilia reticulata), collected from Egyptian water, after exposure to BPA $(50 \mu \mathrm{g} / \mathrm{L}$ of BPA) for 15 days (short term) and 30 days (long term).

Mollusc (Potamopyrgus antipodarum) exposed to concentration of $5 \mu \mathrm{g} / \mathrm{L}$ BPA for 9 weeks led to increase female fecundity [106], also the exposure to concentration $59.4 \mu \mathrm{g} / \mathrm{L}$ BPA for 3 weeks for Mollusc (Mytilus edulis) led to identifiable protein expression changes [107].

Nonylphenol is lipophilic, thus are accumulated in a wide range of marine and aquatic life including algae, crustacean, mollusks, and fish [108]. This is especially important when these organisms are part of the lower trophic level. High concentrations of NP were determined in different tissues of in the fish and wild duck. The low NP concentrations found in some higher animals could be due to the tissue metabolism and elimination. However, information is sparse concerning the metabolic fate of Nonylphenol in aquatic animals [18]. However, Keith et al. [109] measured Nonylphenol in fish tissues of seven species from the Kalamazoo River and in water at the river's confluence with Lake Michigan. They found 41 percent of the tissue samples had measurable concentrations of Nonylphenol with a range of 3.3 to $29.1 \mu \mathrm{g} / \mathrm{kg}$ and a mean value of $12.0 \mu \mathrm{g} / \mathrm{kg}$.

Pesticides and PCBs have strong lipophilic properties, which have caused extensive concerns due to their persistence in the environment and enrichment in food chains [110,111]. These hydropholic compounds are mainly stored in fat tissues and when fats are mobilized, the toxic substances re-enter the circulatory system disturbing the organisms, normal physiology. PCBs have been detected in both fresh and marine water fish in varying amounts depending on size, feeding grounds, position in the food chain. This process is called bioaccumulation or biomagnifaction, and PCB levels in top predators such as bald eagles, lake trout and humans can be millions of times those found in surface water. Because PCBs are soluble in fat (as mentioned before), they stay stored in an organism's fatty tissue and can build to harmful levels over time [112]. 
The main route of exposure to PCBs is via the diet, the major dietary sources of PCBs are fish, in particular oily fish (e.g.salmon, herring, sardines, fresh tuna, swordfish) and those caught in contaminated lakes or rivers, fish oils, meat and dairy products [113]. Because they are usually highly persistent as well as lipophilic, organochlorines tend to accumulate in the fat deposits of animals, especially those with poor metabolic and excretory capabilities for these pollutants, such as marine mammals [114]. In a study conducted in Egypt on the concentration of PCBs (as one of EDCs) in muscle tissues of some cultured freshwater fish, which represent the main meal of fish for the vast majority of Egyptians people, it was found that the concentration ranges from (1.646-22.768 ng/g).This result indicates that agricultural activities (as the fish farm feed on mixed wastes) have affected the water quality of in which the fish live; these organic contaminants are transported to the people through the diet causing a lot of troubles [97].

The bivalve (Brachiodontes sp.) collected along the Egyptian Red Sea coast, the PCBs concentrations were lowest than concentrations of PCBs recorded in mussels collected worldwide. Similarly, the concentrations of PCBs and pesticides observed in coral reef skeleton, collected from Egyptian Red Sea coast, it exhibited moderate differences with low accumulation for most locations [115]. This suggests that PCBs sources may be less prevalent in Egyptian Red Sea environment; consequently, it still does not pose a threat to the ecosystem in this region

Aquatic organisms also readily take up and store DDT and its metabolites. DDT reduced primary production by as much as $50 \%$ at a concentration of $1 \mathrm{ppb}$. Marine fish appear to be very sensitive to DDT: the $96 \mathrm{~h} \mathrm{LC} \mathrm{L}_{50}$ for it ranges between 0.4 and $0.89 \mu / \mathrm{L}$ for a variety of teleosts. Aquatic vertebrates such as fathead minnow and rainbow trout have also been found to contain DDT. Bivalve molluscs, on the other hand, with their ability to concentrate organochlorine pesticides without coming to harm have a $96 \mathrm{~h} \mathrm{LC}_{50}$ greater than $10 \mathrm{mg} / 1$ [116].

In a study of different trophic levels of the North Sea food web, the lipid levels of six major tri, tetra, penta and hexa-BDE congeners in fish were found comparable to the levels in marine invertebrates. Biomagnifications of more than an order of magnitude occurred going from gadoid fish to marine mammals [98]. In the general population, exposure to cadmium occurs primarily through dietary sources, cigarette smoking, and, to a lesser degree, drinking water. Although the metal has no known physiological function, there is evidence to suggest that the cadmium is a potent metallohormone mimics the function of steroid hormones [99].

\section{EDCs IN EGYPTIAN ENVIRONMENT}

Exposure to endocrine active compounds remains poorly characterized in developing countries despite the fact that behavioral practices related to westernization have the potential to influence exposure. BPA is a high production volume chemical that has been associated with metabolic dysfunction as well as behavioral and developmental effects in people, including children. A study on the exposure to phthalates, as ECDs, among premenstrual girls from rural and urban regions in Egypt by Colacino et al. [117], they revealed few differences in the urinary concentrations of specific phthalate metabolites between Egyptian and US girls, perhaps explained by routes/sources of exposure unique to a specific locale. This suggests that exposure to phthalates may be of equal concern in some developing countries as in the US. Colacino et al. [117] noted differences in urinary concentrations of phthalate metabolites by food storage. Additionally, they noted differences in the urinary concentrations of certain phthalate metabolites, mono-benzyl phthalate (MBzP), mono-(3-carboxypropyl) phthalate (MCPP), and mono-isobutyl phthalate (MiBP), between urban and rural individuals when these concentrations were adjusted for urinary dilution using specific gravity. Phthalate exposure alone likely will not explain differences in health effects, including breast cancer, between these urban and rural women in Egypt.

Some traditional Egyptian food, tea and coffee usually served in plastic materials either cups or dishes contain phthalates. Generally, the diet has been considered the prime source of phthalates exposure in the population. High concentrations of Dimethyl phthalate (DMP), Diethyl phthalate (DEP) and Butyl benzyl phthalate (BBP) was recorded in two kinds of traditional food in Egypt ranging from $1.02-2.54 \mu \mathrm{g} / \mathrm{kg}$ [118].

Nahar et al. [119] assess the concentration of BPA in the urine of girls in a province in the center of the Nile Delta in Egypt, similar concentrations of total urinary BPA concentrations were found between girls residing in urban and rural Egypt. The significant association between food storage in plastics and BPA concentrations suggests that diet is an important route for BPA exposure in this population. A closer look at changing food patterns and the consumer market may provide a better understanding of BPA exposure in developing countries.

In the same province in Egypt, Dey et al. [120] found an approximately six times higher incidence of uterine cancer in urban areas, and, in addition, the evidence from Dey et al. [121] recent studies showed an almost four times higher 
urban incidence of breast cancer and ER+ breast cancer. Thus, it is likely that women in urban areas have a higher exposure to environmental hormonal risk factors, possibly xenoestrogens (EDCs). This is especially the case in light of there being no substantial differences between urban and rural women with regards to known risk factors of uterine and breast cancer.

Xenoestrogens are a preventable cause of cancer, and more research at the individual level is required to clearly enumerate a possible association between xenoestrogens with uterine and breast cancers.

El Kholy et al. [122] establish the normal stretched penile length and prevalence of male genital anomalies in fullterm neonates and whether they are influenced by prenatal parental exposure to endocrine-disrupting chemicals in Egypt. A thousand newborns were included; their mothers were subjected to the following questionnaire: parents' age, residence, occupation, contact with insecticides and pesticides, antenatal exposure to cigarette smoke or drugs, family history of genital anomalies, phytoestrogens intake and history of in vitro fertilization or infertility. Free testosterone was measured in 150 neonates in the first day of life. Mean penile length was $3.4 \pm 0.37 \mathrm{~cm}$. A penile length $<2.5 \mathrm{~cm}$ was considered micropenis. Prevalence of genital anomalies was $1.8 \%$ (hypospadias $83.33 \%$ ). There was a higher rate of anomalies in those exposed to endocrine disruptors ((EDCs; 7.4\%) than in the non-exposed $(1.2 \%$; $<<0.0001$; odds ratio $6,95 \%$ confidence interval 2-16). Mean penile length showed a linear relationship with free testosterone and was lower in neonates exposed to EDCs.

\section{CONFLICT OF INTEREST}

The author confirms that this article content has no conflict of interest.

\section{ACKNOWLEDGEMENTS}

Declared none.

\section{REFERENCES}

[1] Sharpe M. Hormones and testis development and the possible adverse effects of environmental chemicals. Toxicol Lett 2001; 120 : 221-32. [http://dx.doi.org/10.1016/S0378-4274(01)00298-3]

[2] Ce'spede R, Lacorte S, Ginebred A, Barcelo' D. Occurrence and fate of alkylphenols and alkylphenol ethoxylates in sewage treatment plants and impact on receiving waters along the Ter River (Catalonia, NE Spain). Environ Pollut 2008; 153: 384-92. [http://dx.doi.org/10.1016/j.envpol.2007.08.026]

[3] Durhan EJ, Lambright CS, Marknen EA, Lazorchak J, Hartig PC. Wison VS. Identification of metabolites of trenbolone acetate in androgenic runoff from a beef feedlot. Environ Health Perspect 2006; 114(1): 65-8.

[4] Fernandez MP, Ikonomou MG, Buchanan I. An assessment of estrogenic organic contaminant in Canadian wastewaters. Sci Total Environ 2007; 373: 250-69.

[http://dx.doi.org/10.1016/j.scitotenv.2006.11.018]

[5] Tan BL, Harker DW, Muller JF, Leusch FD, Tremblay LA, Chapman HF. Modelling of the fate of selected endocrine disruptors in a municipal wastewater treatment plant in South East Queensland, Australia. Chemosphere 2007; 69: 644-54. [http://dx.doi.org/10.1016/j.chemosphere.2007.02.057]

[6] Flemming I, Bent HS. Evaluation of Analytical Chemical Methods for Detection of Estrogens in the Environment. In: Denmark: Danish Ministry of Environment, Danish Environmental Protection Agency 2003; vol. 44: pp. 1-69.

[7] Liu G, Ma J, Li X, Qin Q. Adsorption of bisphenol A from aqueous solution onto activated carbons with different modification treatments. J Hazard Mater 2009; 164(2-3): 1275-80.

[8] Waring RH, Harris RM. Endocrine disrupter: A human risk. Mol Cell Endocrinol 2005; 244: 2-9. [http://dx.doi.org/10.1016/j.mce.2005.02.007]

[9] Avila J, Bonet J, Velasco G, Lacorte S. Determination and occurrence of phthalates, alkylphenols, bisphenol A, PBDEs, PCBs and PAHs in an industrial sewage grid discharging to a Municipal Wastewater Treatment Plant. Sci Total Environ 2009; 407: 4157-67. [http://dx.doi.org/10.1016/j.scitotenv.2009.03.016]

[10] Kidd KA, Becher G, Bergman A, Muir DC, Woodruff TJ. Human and wildlife exposures to EDCs a chapter in "The State of the Science of Endocrine Disrupting Chemicals-2012"UNEP/WHO, ISBN: 978-92-807-3274-0 (UNEP) and 9789241505031 (WHO), 2013 ; (NLM classification: WK 102) 2013.

[11] Wetherill YB, Akingbemi BT, Kanno J, et al. In vitro molecular mechanisms of Bisphenol A action. Reprod Toxicol 2007; $24(2)$ : 178-98. [http://dx.doi.org/10.1016/j.reprotox.2007.05.010]

[12] Welshons WV, Nagel SC, vom Saal FS. Large effects from small exposures. III. Endocrine mechanisms mediating effects of bisphenol A at levels of human exposure. Endocrine 2006; 147: S56-69.

[http://dx.doi.org/10.1210/en.2005-1159] 
[13] Lang IA, Galloway TS, Scarlett A, Henley WE, Depledge M, Wallace DM. Association of urinary bisphenol A concentration with medical disorders and laboratory abnormalities in adults. JAMA 2008; 300: 1303-10. [http://dx.doi.org/10.1001/jama.300.11.1303]

[14] Savabieasfahani M, Kannan K, Astapova O, Evans PN, Padmanabhan V. Developmental programming: differential effects of prenatal exposure to bisphenol-A or methoxychlor on reproductive function. Endocrine 2006; 147: 5956-66. [http://dx.doi.org/10.1210/en.2006-0805]

[15] Munoz de Toro MM, Markey CM, Wadia PR, et al. Perinatal exposure to Bisphenol A alters peripubertal mammary gland development in mice. Endocrinology 2005; 146(9): 4138-47. [http://dx.doi.org/10.1210/en.2005-0340]

[16] Lui Z, Kanjo Y, Mizutani S. Removal mechanisms for endocrine disrupting compounds (EDCs) in wastewater treatment-physical means, biodegradation, and chemical advanced oxidation: A review. Sci Total Environ 2009; 407: 731-48. [http://dx.doi.org/10.1016/j.scitotenv.2008.08.039]

[17] Schultz TW, Sinks GD, Cronin MT. Structure-activity relationships for gene activation oestrogenicity: evaluation of a diverse set of aromatic chemicals. Environ Toxicol 2002; 17: 14-23. [http://dx.doi.org/10.1002/tox.10027]

[18] Vazquez-Duhalt R, Marquez-Rocha F, Ponce E, Licea AF, Viana MT. Nonylphenol, an integrated vision of a pollutant. Scientific Review. Appl Ecol Environ Res 2005; 4(1): 1-25. [http://dx.doi.org/10.15666/aeer/0401_001025]

[19] Ramilo G, Valverde I, Lago J, Vieites JM, Cabado AG. Cytotoxic effects of BADGE (bisphenol A diglycidyl ether) and BFDGE (bisphenol F diglycidyl ether) on Caco-2 cells in vitro. Arch Toxicol 2006; 80: 748-55. [http://dx.doi.org/10.1007/s00204-006-0121-1]

[20] Hyoung UJ, Yang YJ, Kwon SK, et al. Developmental toxicity by exposure to bisphenol A diglycidyl ether during gestation and lactation period in Sprague-Dawley male rats. J Prev Med Pub Health 2007; 40: 155-61. [http://dx.doi.org/10.3961/jpmph.2007.40.2.155]

[21] Poole A, Van Herwijnen P, Weideli H, Thomas MC, Ransbotyn G, Vance C. Review of the toxicology, human exposure and safety assessment for bisphenol A diglycidylether (BADGE). Food Addit Contam 2004; 21: 905-19. [http://dx.doi.org/10.1080/02652030400007294]

[22] Nice HE. Thorndyle, Morrit D, Steele S, Crane M. 2000. Development of Crassostrea gigas larvae is affected by 4-nonylphenol-. Mar Pollut Bull 2000; 40: 491-6. [http://dx.doi.org/10.1016/S0025-326X(99)00230-1]

[23] Nice HE, Morrit D, Crane M, Thorndyle M. Long-term and transgenerationalts of nonylphenol exposure at a key stage in the development of Crassostrea gigas Possible endocrine disruption? Mar Ecol Prog Ser 2003; 256: 293-300. [http://dx.doi.org/10.3354/meps256293]

[24] Baldwin WS, Graham SE, Shea D, LeBlanc GA. Altered metabolic elimination of testosterone and associated toxicity following exposure of Daphnia magna to nonylphenol polyethoxylate. Ecotoxicol Environ 1998; 39: 104-1.

[25] Brown RJ, Conradi M, Depledge MH. Long-term exposure to 4-nonylphenol affects sexual differentiation and growth of the amphipod Corophium volutator (Pallas, 1776). Sci Total Environ 1999; 233: 77-88.

[http://dx.doi.org/10.1016/S0048-9697(99)00181-3]

[26] Atiezar FA, Billinghust Z, Depledge MH. 4-n-nonylphenol and 17- $\beta$ estradiol may induce common DNA effects in developing barnacle larvae. Environ Pollut 2002; 120: 735-8. [http://dx.doi.org/10.1016/S0269-7491(02)00184-7]

[27] Bevan CL, Porter DM, Prasad A, Howard M, Henderson LP. Environmental estrogens alter early development in Xenopus laevis. Environ Health Perspect 2003; 111: 488-96. [http://dx.doi.org/10.1289/ehp.5500]

[28] Magliulo L, Schreibman MP, Cepriano J, Ling J. Endocrine disruption caused by two common pollutant at "acceptable" concentrations. Neurotoxicol Teratol 2000; 24: 71-9. [http://dx.doi.org/10.1016/S0892-0362(01)00190-8]

[29] Yadetie F, Male R. Effects of 4-nonylphenol on gene expression of pituitary hormones in juvenil Atlantic salmon (Salmon salar). Aquat Toxicol 2002; 58: 113-9. [http://dx.doi.org/10.1016/S0166-445X(01)00242-9]

[30] Kyselova V, Peknicova J, Buckiova D, Boubelik M. Effects of p-n-nonylphenol and resveratrol on body and organ weight and in vivo fertility of outbred CD-I mice. Reprod Biol Endocrinol 2003; 1: 30. [http://dx.doi.org/10.1186/1477-7827-1-30]

[31] Zou E, Fingerman M. Synthetic estrogen agents do not interfere with sex differentiation but do inhibit moulting of the water flea, Dhaphnia magna. Ecotoxicol Environ Saf 1997; 38: 281-5. [http://dx.doi.org/10.1006/eesa.1997.1589]

[32] Schlumpf M, Schmid P, Durrer S, et al. Endocrine activity and developmental toxicity of cosmetic UV filters-an update. Toxicology 2004; 
205: 113-22.

[http://dx.doi.org/10.1016/j.tox.2004.06.043]

[33] Balmer ME, Buser HR, M"uller MD, Poiger T. Occurrence of the organic UV filter compounds BP-3, 4-MBC, EHMC, and OC in wastewater, surface waters, and in fish from Swiss lakes. In: Switzerland: Agroscope, Swiss Federal Research Station for Horticultures, Plant Protection Chemistry CH-8820 Wadenswil 2004

[34] James M, McKim Jr, Paul C, et al. Potential Estrogenic and Antiestrogenic Activity of the Cyclic Siloxane Octamethylcyclotetrasiloxane (D4) and the Linear Siloxane Hexamethyldisiloxane (HMDS) in Immature Rats Using the Uterotrophic Assay. Toxicol Sci 2001; 63: $37-46$. [http://dx.doi.org/10.1093/toxsci/63.1.37]

[35] EPA DCN. In Vivo Dermal ADME of C14-D4 in Fischer 344 Rats (to clarify expired air values). In: Siloxane Res. Prog.: Reston 2000.

[36] US EPA. Environmental Protection Agency. Aquatic Life Ambient Water Quality Criteria Nonylphenol (CAS Registry Number 84852-15-3), (CAS Registry Number 25154-52-3) 2005

[37] Zhou T, Ross DG, De Vito MJ, Crofton K. Effects of shortterm in vivo exposure to polybrominated diphenyl ethers on thyroid hormones and hepatic enzyme activities in weanling rats. Toxicol Sci 2001; 61: 76-82. [http://dx.doi.org/10.1093/toxsci/61.1.76]

[38] Kawamur Y, Ogawa Y, Nishimura T, Kikuchi Y, Nishikawa J, Nishihara T. Estrogenic activities of UV stabilizers used in food contact plastics and benzophenone derivatives tested by the yeast two-hybrid assay. J Health Sci 2003; 49: $205-12$. [http://dx.doi.org/10.1248/jhs.49.205]

[39] Nakagawa Y, Tayama K. Estrogenic potency of benzophenone and its metabolites in juvenile female rats. Mol Toxicol 2001; 75: 74-9.

[40] Yamasaki K, Takeyoshim M, Sawaki M, Imatanaka N, Shinoda K, Takatsuki M. Immature rat uterotrophic assay of 18 chemicals and Hershberger assay of 30 chemicals. Toxicology 2003; 183: 93-115. [http://dx.doi.org/10.1016/S0300-483X(02)00445-6]

[41] Satoh K, Nagai F, Aoki N. Several environmental pollutants have binding affinities for both androgen receptor and estrogen receptor a. J Health Sci 2001; 47: 495-501 [http://dx.doi.org/10.1248/jhs.47.495]

[42] Ma R, Cotton B, Lichtensteiger W, Schlumpf M. UV filters with antagonistic action at androgen receptors in the MDA-kb2 cell transcriptional activation assay. Toxicol Sci 2003; 74: 43-50. [http://dx.doi.org/10.1093/toxsci/kfg102]

[43] Suzuki T, Kitamura S, Khota R, Sugihara K, Fujimoto N, Ohta S. Estrogenic and antiandrogenic activities of 17 benzophenone derivatives used as UV stabilizers and sunscreens. Toxicol Appl Pharmacol 2005; 203: 9-17. [http://dx.doi.org/10.1016/j.taap.2004.07.005]

[44] Kelce WR, Stone CR, Laws SC, Earl Gray L, Kemppalnen JA, Wilson EM. Persistent DDT metabolite p,p' DDE is a potent androgen receptor antagonist. Nature 1995; 375: 581-5. [http://dx.doi.org/10.1038/375581a0]

[45] Guillette LJJr. Gross TS, Gross D, Rooney AA, Percival HF. Gonadal steroidogenesis in vitro juvenile alligators obtained from contaminated and control lakes. Environ Health Perspect 1995; 103(Suppl 4): 31-6. [http://dx.doi.org/10.1289/ehp.95103s431]

[46] Falck F, Ricci A, Wolff MS, Godbold J, Deckers P. Pesticides and polychlorinated biphenyl residues in human breast lipids and their relation to breast cancer. Arch Environ Health 1992; 47: 143-6.

[47] Capen CC. Mechanisms of Chemical injury of the thyroid gland. Prog Clin Biol Res 1994; 387: $173-91$.

[48] Carin DA, Guillette LJJr, Pickford DB, Pereival HF, Woodward AR. Sex-steriod and thyrid hormone concentration in juvenile alligators (Alligator mississippiensis) food contaminated and reference lakes in Florida. Environ Toxicol Chem 1998; 17: 446-52. [http://dx.doi.org/10.1897/1551-5028(1998)017<0446:SSATHC $>2.3 . C O ; 2]$

[49] Guillette LJJr, Kools SAE, Gunderson MP, et al. DDT and its Analogues: New Insights into Their Endocrine-Disrupting Effects on Wildlife. In: Norris DO, Carr JA, Eds. Endocrine Disruption: Biological Basis for Health Effects in Wildlife and Humans (pp 331-355). Oxford University Press 2006; p. 447.

[50] Beneck R, Keller E, Vetter B, DeZeeuw RA. Plasma level monitoring of mitotane (o,p'-DDD) and its metabolite (o,p'-DDE) during long-term treatment of cushing's disease with low doses. Eur J Clin Pharmacol 1991; 14: 259-61.

[51] Rolland RM. A review of chemically-induced alterations in thyroid and vitamin A status from field studies of wildlife and fish. J Wildl Dis 200(36): 615-35.

[52] Vos JG, Dybing E, Greim HA, Ladefoged O, Lambre C, Tarazona JV. Health effects of endocrine-disrupting chemicals on wildlife, with special reference to the European situation. Crit Rev Toxicol 2000; 30: 71-133. [http://dx.doi.org/10.1080/10408440091159176]

[53] Brouwer A, Morse DC, Lans MC, Schuur AG, Murk AJ, Klasson-Wehler E. Interactions of persistent environmental organohalogens with the thyroid hormone system: mechanisms and possible consequences for animal and human health. Toxicol Ind Health 1998; 14(1-2): 59-84. [http://dx.doi.org/10.1177/074823379801400107]

[54] McNabb FM. Thyroid Hormones. Englewood Cliffs, NJ: Prentice Hall 1992. 
[55] Zoeller RT, Dowling AL, Herzig CT, Iannacone EA, Gauger KJ, Bansal R. Thyroid hormone, brain development, and the environment. Environ Health Perspect 2002; 110(Suppl. 3): 355-61.

[http://dx.doi.org/10.1289/ehp.02110s3355]

[56] Darnerud PO, Morse D, Klasson-Wehler E, Brouwer A. Binding of a 3,3',4,4'-tetrachlorobiphenyl (CB-77) metabolite to fetal transthyretin and effects on fetal thyroid hormone levels in mice. Toxicology 1996; 106(1-3): 105-14.

[http://dx.doi.org/10.1016/0300-483X(95)03169-G]

[57] Lein PJ, Yang D, Bachstetter AD, Tilson HA, Harry GJ, Mervis RF. Ontogenetic alterations in molecular and structural correlates of dendritic growth after developmental exposure to polychlorinated biphenyls. Environ Health Perspect 2007; 115: 556-63. [http://dx.doi.org/10.1289/ehp.9773]

[58] Porterfield SP. Thyroidal dysfunction and environmental chemicals-potential impact on brain development. Environ Health Perspect 2000; 108(Suppl. 3): 433-8.

[59] McKinney JD. Multifunctional receptor model for dioxin and related compound toxic action: possible thyroid hormone responsive effectorlinked site. Environ Health Perspect 1989; 82: 323-36. [http://dx.doi.org/10.1289/ehp.8982323]

[60] Cheek AO, Kow K, Chen J, McLachlan JA. Potential mechanisms of thyroid disruption in humans: interaction of organochlorine compounds with thyroid receptor, transthyretin, and thyroid-binding globulin. Environ Health Perspect 1999; 107: 273-8.

[http://dx.doi.org/10.1289/ehp.99107273]

[61] Colborn T, Vom Saal FS, Soto AM. Developmental effects of endocrine-disrupting chemicals in wildlife and humans. Environ Health Perspect 1993; 101(5): 378-84.

[http://dx.doi.org/10.1289/ehp.93101378]

[62] Raymond-Whish S, Mayer LP, O'Neal T, et al. Drinking water with uranium below the U.S. EPA water standard causes estrogen receptor dependent responses in female mice. Environ Health Perspect 2007; 115: 1711-6. [http://dx.doi.org/10.1289/ehp.9910]

[63] Veselik DJ, Divekar S, Dakshanamurthy S, et al. Activation of estrogen receptor-alpha by the anion nitrite. Cancer Res 2008; 68: 3950-8. [http://dx.doi.org/10.1158/0008-5472.CAN-07-2783]

[64] Stoica A, Katzenellenbogen BS, Martin MB. Activation of estrogen receptor-alpha by the heavy metal cadmium. Mol Endocrinol 2000; 14: 545-53.

[65] Johnson MD, Kenney N, Stoica A, et al. Cadmium mimics the in vivo effects of estrogen in the uterus and mammary gland. Nat Med 2003; 9: $1081-4$.

[http://dx.doi.org/10.1038/nm902]

[66] Roy SS, Mukherjee S, Mukhopadhyay S, Das SK. Differential effect of cadmium on cholinephosphotransferase activity in normal and cancerous human mammary epithelial cell lines. Mol Cancer Ther 2004; 3(2): 199-204.

[67] Brooks SC, Locke ER, Soule HD. Estrogen receptor in a human cell line (MCF-7) from breast carcinoma. J Biol Chem 1973; 248 : 6251-3.

[68] Brama M, Gnessi L, Basciani S, et al. Cadmium induces mitogenic signaling in breast cancer cell by an ERalpha-dependent mechanism. Mol Cell Endocrinol 2007; 264: 102-8.

[http://dx.doi.org/10.1016/j.mce.2006.10.013]

[69] Martinez-Campa C, Alonso-Gonzalez C, Mediavilla MD, et al. Melatonin inhibits both ER alpha activation and breast cancer cell proliferation induced by a metalloestrogen, cadmium. J Pineal Res 2006; 40: 291-6. [http://dx.doi.org/10.1111/j.1600-079X.2006.00315.x]

[70] Liu Z, Yu X, Shaikh ZA. Rapid activation of ERK1/2 and AKT in human breast cancer cells by cadmium. Toxicol Appl Pharmacol 228: 286-94. [http://dx.doi.org/10.1016/j.taap.2007.12.017]

[71] Dubrow R, Wegman DH. Cancer and occupation in Massachusetts: a death effects of nonylphenol exposure at a key stage in the development of Crassostrea gigas certificate study. Am J Ind Med 1984; 6: 207-30.

[http://dx.doi.org/10.1002/ajim.4700060305]

[72] Cantor KP, Stewart PA, Brinton LA, Dosemeci M. Occupational exposures and female breast cancer mortality in the United States. J Occup Med 1994; 37: 336-48.

[http://dx.doi.org/10.1097/00043764-199503000-00011]

[73] Nagata C, Nagao Y, Shibuya C, Kashiki Y, Shimizu H. Urinary cadmium and serum levels of estrogens and androgens in postmenopausal Japanese women. Cancer Epidemiol Biomarkers Prev 2005; 14(3): 705-8. [http://dx.doi.org/10.1158/1055-9965.EPI-04-0619]

[74] Cassidy A, Bingham S, Setchell KD. Biological effects of a diet of soy protein rich in isoflavones on the menstrual cycle of premenopausal women. Am J Clin Nutr 1994; 60(3): 333-40.

[75] West MC, Anderson L, McClure N, Lewis SE. Dietary oestrogens and male fertility potential. Hum Fertil (Camb) 2005; 8(3): 197-207. [http://dx.doi.org/10.1080/14647270500030266]

[76] Dillingham BL, McVeigh BL, Lampe JW, Duncan AM. Soy protein isolates of varying isoflavones content exert minor effects on serum 
reproductive hormones in healthy young male. J Nutr 2005; 135(3): 584-91.

[77] Mitchell JH, Cawood E, Kinniburgh D, Provan A, Collins AR, Irvine DS. Effect of a phytoestrogens food supplement on reproductive health in normal males. Clin Sci 2001; 100(6): 613-8.

[http://dx.doi.org/10.1042/cs1000613]

[78] Messina M, McCaskill-Stevens W, Lampe JW. Addressing the soy and breast cancer relationship: review, commentary and workshop proceedings. J Natl Cancer Inst 2006; 98(18): 1275-84. [http://dx.doi.org/10.1093/jnci/djj356]

[79] De Lemos M. Effect of soy phytoestrogens genistein and daidzein on breast cancer growth. Ann Pharmacother 2001; 35(9): 1118-21. [http://dx.doi.org/10.1345/aph.10257]

[80] Monteiro SC, Boxall AB. Occurrence and fate of human pharmaceuticals in the environment. In: Whitacre DM, Ed. Reviews of Environ Contaminat and Toxicol. New York: Springer 2010; pp. 53-154. [http://dx.doi.org/10.1007/978-1-4419-1157-5_2]

[81] Citulski JA, Farahbakhsh K. Fate of endocrine-active compounds during municipal biosolids treatment: A review. Environ Sci Technol 2010; 44(22): 8367-76. [http://dx.doi.org/10.1021/es102403y]

[82] Edwards M, Topp E, Metcalfe CD, et al. Pharmaceutical and personal care products in tile drainage following surface spreading and injection of dewatered municipal biosolids to an agricultural field. Sci Total Environ 2009; 407(14): 4220-30. [http://dx.doi.org/10.1016/j.scitotenv.2009.02.028]

[83] Guo Z, Feng R. Ultrasonic irradiation-induced degradation of low-concentration bisphenol A in aqueous solution. J Hazard Mater 2009; 163: 855-60. [http://dx.doi.org/10.1016/j.jhazmat.2008.07.038]

[84] Suzuki T, Nakagawa Y, Takano I, Yaguchi K, Yasuda K. Environmental fate of Bisphenol A and its biological metabolites in river water and their xenoestrogenic activity. Environ Sci Technol 2004; 38(8): 2389-96. [http://dx.doi.org/10.1021/es030576z]

[85] Yamamoto T, Yasuhara A, Shiraishi H, Nakasugi O. Bisphenol A in hazardous waste landfill leachates. Chemosphere 2001; 42(4): 415-8. [http://dx.doi.org/10.1016/S0045-6535(00)00079-5]

[86] Kolpin DW, Furlong ET, Meyer MT, et al. Occurrence of endocrine-disrupting chemicals in sewage and sludge samples in Toronto, Canada. Water Qual Res J 2004; 39(1): 57-63.

[87] Belfroid A, Velzen MV, Horst Bvd, Vethaak D. Occurrence of bisphenol A in surface water and uptake in fish: evaluation of field measurements. Chemosphere 2002; 49: 97-103. [http://dx.doi.org/10.1016/S0045-6535(02)00157-1]

[88] Wenzel A, Küchler T, Henschel K, Schnaak W, Diedrich M, Müller J. Concentration of estrogenic active substances in the environment. In: Germany: Fraunhofer-Institut, Schmallenberg Germany (in German) 1998.

[89] Crain DA, Eriksen M, Iguchi T, et al. An ecological assessment of bisphenol-A: evidence from comparative biology. Reprod Toxicol 2007; 24: $225-39$.

[http://dx.doi.org/10.1016/j.reprotox.2007.05.008]

[90] Funakoshi G, Kasuya S. Influence of an estuary dam on the dynamics of bisphenol A and alkylphenols. Chemosphere 2009; 75 : 491-7. [http://dx.doi.org/10.1016/j.chemosphere.2008.12.050]

[91] Sajiki J, Yonekubo J. Leaching of bisphenol-A (BPA) to seawater from polycarbonate plastic and its degradation by reactive oxygen species. Chemosphere 51: 55-62. [http://dx.doi.org/10.1016/S0045-6535(02)00789-0]

[92] Kang JH, Kondo F. Bisphenol-A degradation in seawater is different from that in river water. Chemosphere 2005; 60: 1288-92. [http://dx.doi.org/10.1016/j.chemosphere.2005.01.058]

[93] Thomas KV, Hurst MR, Matthiessen P, Sheahan D, Williams RJ. Toxicity characterization of organic contaminants in stormwaters from an agricultural headwater stream in South East England. Water Res 2001; 35: 2411-6. [http://dx.doi.org/10.1016/S0043-1354(00)00535-2]

[94] Lee H, Peart ET, Chan J, Gris G. Occurrence of endocrine-disrupting chemicals in sewage and sludge samples in Toronto, Canada. Water Qual Res J 2004; 39(1): 57-63.

[95] Bennie DT, Sullivan CA, Lee H, Peart TE, Maguire RJ. Occurrence of alkylphenols and alkylphenol mono- and di-ethoxylates in natural waters of the aurentian Great Lakes basin and the upper St.Lawrence River. Sci Total Environ 1997; 193: 263-75. [http://dx.doi.org/10.1016/S0048-9697(96)05386-7]

[96] Lintelmann J, Katayama A, Kurihara N, Shore L, Wenzel A. Endocrine disruptors in the environment - (IUPAC Technical Report). Pure Appl Chem 2003; 75(5): 631-81.

[http://dx.doi.org/10.1351/pac200375050631]

[97] Abdallah MA, Morsy F. Persistent organochlorine pollutants and metals residues in sediment and freshwater fish species cultured in a shallow lagoon, Egypt. Environ Technol 2013; 34: 2389-99. [http://dx.doi.org/10.1080/09593330.2013.770561] 
[98] Siddiqi MA, Laessig RH, Reed KD. Polybrominated Diphenyl Ethers (PBDEs): New Pollutants-Old Diseases. Clin Med Res 2003; 1(4): 281-90. [http://dx.doi.org/10.3121/cmr.1.4.281]

[99] Choe SY, Kim SJ, Kim HG, et al. Evaluation of estrogenicity of major heavy metals. Sci Total Environ 2003; 312 : 15-21. [http://dx.doi.org/10.1016/S0048-9697(03)00190-6]

[100] Alexander HC, Dill DC, Smith LW, Guiney PD, Dorn PB. Bisphenol A: acute aquatic toxicity. Environ Toxicol Chem 1988; 7: 19-26. [http://dx.doi.org/10.1002/etc.5620070104]

[101] Lindholst C, Pedersen KL, Pedersen SN. Estrogenic response of bisphenol a in rainbow trout (Oncorhynchus mykiss). Aquat Toxicol 2000; 48: 87-94. [http://dx.doi.org/10.1016/S0166-445X(99)00051-X]

[102] Alo R, Facciolo RM, Madeo M, Guisi G, Carelli A, Canonaco M. Effects of the xenoestrogen bisphenol A in dicephalic regions of the teleost fish Coris julis occur preferentially via distinct somatostatin receptor subtypes. Brain Res Bull 2005; 65: $267-73$. [http://dx.doi.org/10.1016/j.brainresbull.2005.01.006]

[103] Pastva SD, Villalobos SA, Kannan K, Giesy JP. Morphological effects of Bisphenol A on the early life stages of medaka (Oryzias latipes). Chemosphere 2001; 45: 535-41.

[http://dx.doi.org/10.1016/S0045-6535(01)00018-2]

[104] Honkanen JO, Holopainen IJ, Kukkonen JV. Bisphenol A induces yolk sac oedema and other adverse effects landlocked salmon (Salmo salar m.chebago) yolk-sac fry. Chemosphere 2004; 55: 187-96. [http://dx.doi.org/10.1016/j.chemosphere.2003.10.028]

[105] El Shaer FM, Khalaf-Allah HM, Bakry S. Histopathological Alterations in Gills of Some Poecilid Fishes after Exposure to Bisphenol A. World J Fish Marine Sci 2013; 5: 693-700.

[106] Jobling S, Casey D, Rodgers-Gray T, et al. Comparative responses of mollusks and fish to environmental estrogens and estrogenic effluent. Aquat Toxicol 2003; 65: 205-20 [http://dx.doi.org/10.1016/S0166-445X(03)00134-6]

[107] Apraiz I, Mi J, Cristobal S. Identification of preoteomic signatures of exposure to marine pollutants in mussels (Mytilus edulis). Mol Cell Prot 2006; 5(7): 1274-85.

[http://dx.doi.org/10.1074/mcp.M500333-MCP200]

[108] Heinis LJ, Knuth L, Liber K, Sheedy BR, Tunell RL, Ankley GT. Persistence and distribution of 4-nonylphenol following repeated application to the littoral. Environ Toxicol Chem 1999; 18: 363-75. [http://dx.doi.org/10.1002/etc.5620180302]

[109] Keith TL, Snyder SA, Naylor CG, et al. Identification and quantitation of nonylphenol ethoxylates and nonylphenol in fish tissues from Michigan. Environ Sci Technol 2001; 35: 10-3. [http://dx.doi.org/10.1021/es001315h]

[110] Marth P, Oxynos K, Schmitzer J, Schramm KW, Kettrup A. Levels of chlorinated hydrocarbons (CHC) in Breams Abramis brama from the river Elbe (A contribution to the federal environmental specimen bank). Chemosphere 1997; 34: $2183-92$.

[http://dx.doi.org/10.1016/S0045-6535(97)00077-5]

[111] Fernández MA, Alono C, Gonzalez MJ, Hernandez LM. Occurrence of organochlorine insecticides, PCBs and PCB congeners in waters and sediments of the River (Spain). Chemosphere 1999; 38: 33-43. [http://dx.doi.org/10.1016/S0045-6535(98)00167-2]

[112] Herrick RF, McClean MD, Meeker JD, Baxter LK, Weymouth GA. An unrecognized source of PCB contamination in schools and other buildings. Environ Health Perspect 2004; 112(10): 1051-3. [http://dx.doi.org/10.1289/ehp.6912]

[113] Food Standards Agency (FSA). UK Dioxins and dioxin-like PCBs in the UK diet: 2001 total diet study samples 2003.

[114] Tanabe S, Watanabe S, Kan H, Tatsukawa R. Capacity and mode of PCB metabolism in small cetaceans. Mar Mamm Sci 1988; 4: 103-24. [http://dx.doi.org/10.1111/j.1748-7692.1988.tb00191.x]

[115] Khalid A, El Nemr A, Said TO, El-Sikaily A, Abd-Alla AM. Polychlorinated biphenyls and chlorinated pesticides in mussels from the Egyptian Red Sea coast. Chemosphere 2004; 54: 1407-12. [http://dx.doi.org/10.1016/j.chemosphere.2003.10.042]

[116] WFPHA: World Federation of Public Health Associations. Persistent organic pollutants and human health. Washington. 2000.

[117] Colacino JA, Soliman AS, Calafat AM, et al. Exposure to phthalates among premenstrual girls from rural and urban Gharbiah, Egypt: A pilot exposure assessment study. Environ Health 2011; 10: 1-8. [http://dx.doi.org/10.1186/1476-069X-10-40]

[118] Mohamed MA, Ammar AS. Quantitative analysis of Phthalates in traditional Egyptian foods (Koushary and Foul edams), black tea, instant coffee and bottled waters by solid extraction-capillary gas chromatography-mass spectroscopy. Ameri J Food Technol 2008; 3(5): 341-6. [http://dx.doi.org/10.3923/ajft.2008.341.346]

[119] Nahar MS, Soliman AS, Colacino JA, et al. Urinary Bisphenol A concentrations in girls from rural and urban Egypt: a pilot study. Environ 
Health 2012; 11: 1-8.

[http://dx.doi.org/10.1186/1476-069X-11-20]

[120] Dey S, Hablas A, Seifeldin IA, et al. Urban-rural differences of gynaecological malignancies in Egypt (1999-2002). BJOG 2010; 117: 348-55. [http://dx.doi.org/10.1111/j.1471-0528.2009.02447.x]

[121] Dey S, Soliman AS, Hablas A, Seifeldin IA, Ismail K, Ramadan M. Urban rural differences in breast cancer incidence by hormone receptor status across 6 years in Egypt. Breast Cancer Res Treat 2010; 120(1): 149-60.

[122] El Kholy M, Hamza RT, Saleh M, El Sedfy H. Penile length and genital anomalies in Egyptian male newborns: epidemiology and influence of endocrine disruptors. J Pediatr Endocrinol Metab 2013; 26(5-6): 509-13. [http://dx.doi.org/10.1515/jpem-2012-0350]

Received: June 12, 2014

(C) Maha Ahmed Mohamed Abdallah; Licensee Bentham Open.

This is an open access article licensed under the terms of the Creative Commons Attribution-Non-Commercial 4.0 International Public License (CC BY-NC 4.0) (https://creativecommons.org/licenses/by-nc/4.0/legalcode), which permits unrestricted, non-commercial use, distribution and reproduction in any medium, provided the work is properly cited. 